Niepełnosprawność. Dyskursy pedagogiki specjalnej

Nr 25/2017

Disability. Discourses of special education

No. 25/2017

Katarzyna Parys

Uniwersytet Pedagogiczny w Krakowie

\title{
Trajektoria życia osób z niepełnosprawnością intelektualną w stopniu lekkim
}

Tematem rozważań podjętych w artykule jest bieg życia osób z niepełnosprawnością intelektualną w stopniu lekkim. Analizie poddano wydarzenia, które niezwykle wyraźnie wpisują się w życiorysy wspomnianych osób, warunkując ich losy społeczne. Punkty wyznaczające granice prowadzonych rozważań to czas stwierdzenia niepełnosprawności i czas, w którym orzeczenie o niepełnosprawności przestaje obowiązywać. W końcowej części artykułu zawarto postulaty, których wdrożenie mogłoby sprzyjać wyrównywaniu szans rozwojowych i przeciwdziałać marginalizacji społecznej osób z niepełnosprawnością intelektualną w stopniu lekkim.

Słowa kluczowe: osoba z lekką niepełnosprawnością intelektualną, trajektoria życiowa, orzekanie o niepełnosprawności ucznia, losy edukacyjne, aktywność zawodowa

\section{The life trajectory of person with mild intellectual disability}

The presented paper discusses he use of a life-event history approach to understand the life trajectories of people with mild intellectual disabilities. There were recognized and analysed life events which had a very strong impact on participants' life and directly affected their social fate. The critical events that appeared to influence one's life was identification of disability and the time it was no longer valid. To make some generalizations and postulates within formulated conclusions, this paper is a contribution to promote equal opportunities and prevent social marginalization of people with mild intellectual disability.

Keywords: person with mild intellectual disability, trajectory of life, identification of a student's disability, educational paths, vocational activity

\section{Wprowadzenie}

Początkowo trajektoria w naukach społecznych była rozumiana jako struktura procesowa, która wiąże się z umieraniem, cierpieniem, bezładem, nieprzewidywalnością, utratą kontroli nad przebiegiem zdarzeń. Taki sposób rozumienia tej kategorii pojęciowej prezentował Fritz Schűtze i Gerhard Riemann. W miarę kolejnych lat zakres znaczeniowy pojęcia trajektorii uległ znacznemu poszerze- 
niu. Obecnie jest ujmowana jako kategoria służąca do badania zmienności życia, niezależnie od tego czy zmienność ta ma dramatyczny charakter, prowadzi do destrukcji, bezradności, cierpienia, czy też związana jest z poczuciem radości, zadowolenia i dobrostanu. Jednym z najczęściej występujących kontekstów, w jakich pojawia się pojęcie trajektorii, jest ujmowanie jej jako kategorii służącej do badania przebiegu życia ludzkiego [Zakrzewska-Manterys 1995, s. 42]. Trajektoria życiowa jest ustrukturalizowaną przez społeczeństwo ścieżką, którą kroczy aktor społeczny zmierzając do końca cyklu swego życia [Hopper, za: Mikiewicz 2005, s. 82]. Charakteryzuje się ona nieprzewidywalnością zdarzeń, które zazwyczaj wymuszają konieczność jego reorganizacji, niejednokrotnie prowadzą do utraty kontroli nad przebiegiem własnego życia. Kształt trajektorii społecznej kreślony jest przez siły zewnętrzne, stymulujące lub ograniczające działania jednostki. O trajektorii można mówić zarówno w odniesieniu do pojedynczych osób (trajektoria indywidualna), jak i do procesów społecznych (trajektoria kolektywna, zbiorowa, społeczna) [Rokuszewska-Pawełek 1997].

Przez zastosowanie w tytule artykułu terminu "trajektoria", chciałam zaakcentować, że losy osób uzyskujących diagnozę niepełnosprawności intelektualnej w stopniu lekkim obfitują w narzucone zewnętrznie, opresyjne, wymykające się spod kontroli, doświadczenia. Wskutek okoliczności ograniczających swobodę działania osoby te często zmuszone są poddać się nurtowi zdarzeń, który je niesie i wprowadza w wyznaczone miejsce przestrzeni społecznej, narzuca role, od których nie sposób się uwolnić. Czynnikiem, który przymusza osoby niepełnosprawne intelektualnie do uległości wobec sił społecznych, do biernego poddania się losowi, jest nie tylko sprawcza moc pojawiających się okoliczności, ale również bezradność charakteryzująca funkcjonowanie tych osób [Gajdzica 2007], nieporadność ujawniana w obliczu nowych, nieznanych sytuacji.

Elementy trajektorii, które w szczególny sposób decydują o losie społecznym osób z niepełnosprawnością intelektualną w stopniu lekkim, to uzyskanie orzeczenia o niepełnosprawności intelektualnej, przyjęcie statusu ucznia niepełnosprawnego, wybór miejsca realizacji kształcenia specjalnego, zakończenie drogi edukacyjnej łączące się z zarzuceniem etykiety niepełnosprawności. Wymienione elementy podobnie prezentują się w biografiach znacznej liczby osób z niepełnosprawnością intelektualną w stopniu lekkim, co pozwala mówić o zbiorowej trajektorii, nie negując faktu występowania odbiegających od niej kształtem trajektorii indywidualnych. 


\section{Orzeczenie o niepełnosprawności intelektualnej - etykieta i glejt}

Rozważając rolę orzeczenia o niepełnosprawności intelektualnej dla kształtowania życiorysów dzieci uzyskujących ten dokument należy wziąć pod uwagę czas, w którym prowadzony jest proces diagnostyczny. Działania te nie przypadają na pierwsze miesiące i lata życia, lecz są podejmowane wobec dzieci, które wchodzą już w rolę ucznia. Orzekanie o niepełnosprawności intelektualnej w stopniu lekkim przed podjęciem edukacji szkolnej jest zabiegiem trudnym, niecelowym, a nawet szkodliwym ${ }^{1}$. Granice czasowe, w jakich uczniowie uzyskują orzeczenie potwierdzające występowanie niepełnosprawności intelektualnej w stopniu lekkim, są bardzo rozległe. Niektórzy dysponują takim dokumentem już w klasie pierwszej szkoły podstawowej, inni natomiast otrzymują go w latach późniejszych. Nierzadko bywa, że pierwsze orzeczenie jest wystawiane dopiero wówczas, gdy uczeń realizuje naukę na drugim lub trzecim, a nawet czwartym etapie edukacyjnym [Pańczyk 1996, s. 581; Chrzanowska 2010, s. 144; Sadownik 2011, s. 105-106]. Z badań Joanny Głodkowskiej [1999, s. 16] wynika, że średnio o niepełnosprawności intelektualnej² orzeka się w 11 roku życia dziecka.

Poza odmiennym czasem uzyskania orzeczenia, różne są drogi dojścia do diagnozy niepełnosprawności intelektualnej w stopniu lekkim. Rekonstruując biografie uczniów zakwalifikowanych do kształcenia specjalnego z racji niepełnosprawności intelektualnej w stopniu lekkim, Alicja Sadownik [2011] wskazuje na wydarzenia i nieszczęśliwe zbiegi okoliczności, jakich doświadczają wspomniani uczniowie. Elementem, który pojawia się we wszystkich biografiach, są niepowodzenia szkolne warunkowane różnymi przyczynami. Bywa, że jest to niski poziom możliwości ucznia, który nie pozwala sprostać wymaganiom szkolnym pomimo wysiłku dziecka i korzystnych oddziaływań domu rodzinnego. W innych przypadkach daje znać o sobie brak zainteresowania zadaniami szkolnymi, unikanie obowiązków, wejście w nieodpowiednie towarzystwo, brak akceptacji w zespole rówieśniczym, a nawet doświadczanie przemocy fizycznej w szkole. Zjawiskiem, które z racji powszechności zwraca uwagę, jest niekorzystna sytuacja kulturowa

1 O trudności decyduje fakt, iż objawy w funkcjonowaniu psychospołecznym dziecka, odczytane jako wskaźniki niepełnosprawności intelektualnej, mogą mieć też inne źródło. Orzeczenie o niepełnosprawności intelektualnej w stopniu lekkim wydawane przez poradnię psychologiczno-pedagogiczną, jest dokumentem, który nie znajduje zastosowania poza szkolnym systemem edukacyjnym, stąd wystawianie tego dokumentu wobec dziecka, które nie występuje jeszcze w roli ucznia jest niecelowe, a nawet szkodliwe. Należy podejrzewać, że z chwilą wystawienia diagnozy, otoczenie nadmiernie eksponuje trudności i braki dziecka, natomiast niedostrzegane są obszary normalności i mocne strony jego funkcjonowania. Ponadto wszelkie trudności ujawniane przez dziecko są postrzegane jako bezwzględna konsekwencja ujawnionej niepełnosprawności. W rezultacie, dochodzi do nadmiernego minimalizowania wymagań stawianych wobec dziecka, niezasadnego wykluczania go z pewnych działań i aktywności.

2 W pracy, na którą się powołuję, Joanna Głodkowska stosowała termin „upośledzenie umysłowe”. 
i socjalna rodzin wychowujących dzieci z diagnozą lekkiej niepełnosprawności intelektualnej. Od wielu lat kolejni badacze [Ostrowska, Firkowska-Mankiewicz 1978; Kościelska 1984, Wojciechowski 1990, Borzyszkowska 1997, Głodkowska 1999, Kozubska 2000, Gajdzica 2007] potwierdzają, iż wszystkie wskaźniki statusu społecznego, warunków życia i poziomu kultury, w populacji rodzin wychowujących dzieci niepełnosprawne intelektualnie $\mathrm{w}$ stopniu lekkim, są bardzo niekorzystne i znacznie odbiegają od tych, które charakteryzują populację generalną. To właśnie zaniedbaniom środowiskowym przypisuje się znaczący udział w powstawaniu niepełnosprawności intelektualnej [zob. Kościelska 1995]. Mogą one wyzwalać lub potęgować nieprawidłowości biologiczne, bądź też samoistnie doprowadzić do zaburzenia funkcjonowania poznawczego.

Na podstawie doświadczeń zgromadzonych w trakcie badań własnych Alicja Sadownik [2011, s. 155] stwierdza, że "diagnoza o lekkiej niepełnosprawności intelektualnej jest zabiegiem wtórnym wobec problemów społecznych, szkolnych i zaniedbań środowiskowych; aktem przemocy symbolicznej [...] narzucającym nowy tok wnioskowania o losie społecznym tych osób". Z chwilą uzyskania orzeczenia o niepełnosprawności intelektualnej, wszelkie działania ucznia mogą być nadmiernie łączone ze zdiagnozowanym zaburzeniem, wyjaśniane jako oczywisty wynik niepełnosprawności.

Wracając do kwestii dużego zróżnicowania czasowego dotyczącego diagnozowania niepełnosprawności intelektualnej w stopniu lekkim, należy zwrócić uwagę, że wnioskodawcami ubiegającymi się o podjęcie działań mających doprowadzić do wystawienia orzeczenia są rodzice lub prawni opiekunowie dziecka. Zatem czas uzyskania orzeczenia jest warunkowany czasem podjęcia przez nich decyzji o złożeniu w poradni psychologiczno-pedagogicznej stosownego wniosku. Rodzice niejednokrotnie wstrzymują się przed uruchomieniem koniecznych działań, a bywa i tak, że nigdy ich nie podejmują. Źródłami oporu rodziców wobec wnioskowania o skierowanie dziecka na badania specjalistyczne może być:

- brak orientacji w zakresie faktycznych umiejętności i trudności dziecka, niedostrzeganie odstępstw od prawidłowości rozwojowych lub bagatelizowanie ich;

- idealizowanie rzeczywistego obrazu funkcjonowania dziecka, przypisywanie winy za dostrzegane trudności czynnikom zewnętrznym;

- swoiste poczucie wstydu, wynikające z faktu bycia rodzicem dziecka niepełnosprawnego intelektualnie;

- chęć uniknięcia nadania dziecku etykietującej diagnozy;

- brak świadomości na temat roli orzeczenia o niepełnosprawności dla zmiany sytuacji szkolnej dziecka lub błędne przekonania w tym zakresie.

Niezależnie od czasu, w jakim uczeń uzyska orzeczenie o niepełnosprawności, jest to istotny punkt w biegu jego życia. Potwierdzenie i nazwanie niepełnosprawności może prowadzić do zmiany statusu w percepcji własnej i w odbiorze 
otoczenia. Dziecko, które przez lata funkcjonowało jako pełnosprawne, z dnia na dzień staje się dzieckiem niepełnosprawnym. Wprawdzie orzeczenie wystawione przez poradnię psychologiczno-pedagogiczną jest dokumentem mającym zastosowanie jedynie w sytuacjach szkolnych, jednak cenzus niepełnosprawności może być - i najczęściej jest - rozpowszechniany również na wszelkie sytuacje pozaszkolne. Amadeusz Krause [2010, s. 106], podkreślając rolę dokumentu potwierdzającego niepełnosprawność, stwierdza, że diagnoza współtworzy upośledzenie.

Uczeń z niepełnosprawnością korzysta z prawa do kształcenia specjalnego, które może być realizowane na terenie szkoły specjalnej, placówki integracyjnej lub ogólnodostępnej. Decyzję dotyczącą miejsca edukacji dziecka niepełnosprawnego podejmują jego prawni opiekunowie. Coraz rzadziej stwierdzenie niepełnosprawności intelektualnej lekkiego stopnia skutkuje przeniesieniem dziecka do szkoły specjalnej. Powodem nie jest tylko malejąca liczba szkół specjalnych, ale również społeczna niechęć wobec placówek o charakterze izolacyjnym. Rodzice chcąc uniknąć rozwiązań, które wyraźnie naznaczają3 dziecko i izolują go od dotychczasowej społeczności lokalnej, jako miejsce edukacji chętniej wybierają placówki integracyjne lub szkoły ogólnodostępne. Trzeba jednak zauważyć, że nawet wówczas gdy dziecko pozostanie w dotychczasowym zespole klasowym pod opieką znanych mu nauczycieli, to za sprawą orzeczenia o potrzebie kształcenia specjalnego organizacja jego nauczania ulega pewnym zmianom. Nauczyciele będą mieli nie tylko prawo, ale także obowiązek zastosowania rozwiązań wspomagających dziecko w procesie edukacji. Zostanie opracowany indywidualny program edukacyjno-terapeutyczny, który powinien uwzględniać potrzeby i możliwości edukacyjne oraz rozwojowe niepełnosprawnego ucznia, a także akcentować rozwiązania dydaktyczne pozwalające optymalizować jego rozwój. Uczeń zostanie objęty dodatkowymi zajęciami rewalidacyjnymi, które powinny wzmacniać predyspozycje rozwojowe, zmierzać do eliminowania nieprawidłowości, zapobiegać ich pogłębianiu.

Fakt, iż naznaczenie dziecka etykietą niepełnosprawności jest koniecznym warunkiem, by placówka edukacyjna uruchomiła działania sprzyjające pełniejszemu rozwojowi, dostosowane do możliwości ucznia, wydaje się być paradoksem i w pewnym stopniu ujawnia niewydolność systemu edukacyjnego. W przypadku braku dokumentu stwierdzającego niepełnosprawność podjęcie działań

Na marginesie należy zaznaczyć, że każda placówka, w której jest realizowane kształcenie specjalne może być naznaczającą dla ucznia. O ile w przypadku szkół specjalnych sygnały świadczące o stygmatyzacji dają znać o sobie w środowisku pozaszkolnym, to w szkołach masowych i integracyjnych naznaczanie zachodzi w obrębie klasy i szkoły. Wiąże się ono przede wszystkim z postrzeganiem przez pełnosprawnych rówieśników (kolegów, uczniów tej samej szkoły) niepełnosprawności danej osoby. Z kolei klasy specjalne i integracyjne mogą być traktowane jako specyficzne oddziały na terenie szkoły. Sama przynależność do tej grupy powoduje naznaczanie jej członków już w obrębie danej szkoły (zob. Olszewski, Parys 2004). 
odwołujących się do szeroko rozumianej indywidualizacji w nauczaniu jest znacznie utrudnione. Uczeń nieposiadający orzeczenia, które jest swoistym glejtem zapewniającym prawo do uzyskania wsparcia edukacyjnego, jest zobligowany realizować zadania odpowiadające rygorom programowym, zadania, które niejednokrotnie przerastają jego możliwości. W takiej sytuacji, wbrew popularyzowanym hasłom, iż to szkoła powinna dostosowywać się do ucznia, zachodzą działania wymuszające konieczność dostosowywania się ucznia do szkoły.

Poza formalnymi modyfikacjami w procesie edukacji szkolnej, które ustawowo przysługują uczniom niepełnosprawnym, trzeba się liczyć ze zmianą społecznej percepcji dziecka posiadającego orzeczenie o niepełnosprawności intelektualnej. Pożądana zmiana nastąpi wówczas, gdy opiekunowie wykażą zrozumienie dla trudności i braków ujawnianych przez dziecko, podejmując równocześnie celowe działania minimalizujące jego problemy, usprawniające umiejętność korzystania z zasobów, wzmacniające potencjał. Istotne jest jednak, by nie ograniczali się oni wyłącznie do braków i deficytów, ale umieli dostrzec pozytywne właściwości dziecka i jego zasoby. Diagnoza spełniająca te warunki to diagnoza zorientowana na rozwój dziecka [zob. Obuchowska 1997]. Jej przeciwieństwem jest diagnoza dla selekcji, w wyniku której może dochodzić do zaniechania działań wspomagających rozwój ucznia, bądź też nienaturalnego obniżenia wymagań, przesadnego spowolnienia tempa pracy, infantylizacji procesu edukacyjnego.

Orzeczenie o niepełnosprawności intelektualnej i potrzebie kształcenia specjalnego, a także postawy środowiska, są czynnikami, które warunkują samoocenę dziecka zdiagnozowanego jako niepełnosprawne intelektualnie w stopniu lekkim. Walorami człowieka, do których w naszej rzeczywistości społecznej przywiązuje się szczególną wagę, są: wysoki intelekt, sprawność rozumowania i bogata umysłowość. Zdolności te są nade wszystko waloryzowane w procesie edukacji. To one zazwyczaj decydują o uczniowskich sukcesach i porażkach, wyznaczają pozycję $w$ hierarchii szkolnej. W przypadku niedoceniania pozaintelektualnych walorów, dzieci zdiagnozowane jako niepełnosprawne intelektualnie w stopniu lekkim będą nieustannie spychane na margines życia szkolnego, skazane na porażkę i wykluczenie. Na skutek negatywnych doświadczeń edukacyjnych będą utwierdzały się w przekonaniu o własnej odmienności, niedoskonałości, bezużyteczności, upośledzeniu. Ponieważ świadomość własnej niepełnosprawności. jest czynnikiem, który może blokować rozwój, hamować aktywność, bądź też prowokować do działań niepożądanych społecznie, koniecznym jest, by otoczenie dostrzegało, wskazywało i rozwijało te zasoby dziecka niepełnosprawnego intelektualnie, które pozwolą odnieść sukces, będą budziły uznanie osób znaczących, a tym samym zrekompensują niekorzystną ocenę własną i innych w zakresie funkcjonowania poznawczego [zob. Kościelska 1984, s. 352]. 
Wpływ środowiska na kształtowanie się samooceny osób z niepełnosprawnością intelektualną w stopniu lekkim ujawnili w swych badaniach L. Strang, J.M. Coleman, E. Zigler i R.M. Hodapp [za: Pilecka 2000, s. 25]. Autorzy porównali samoocenę uczniów niepełnosprawnych intelektualnie edukowanych w warunkach szkoły specjalnej, klasy integracyjnej oraz klasy ruchomej, która umożliwia uczniom niepełnosprawnym realizować niektóre zajęcia wespół z pełnosprawnymi rówieśnikami, a inne $\mathrm{w}$ grupie homogenicznej. Badania potwierdziły, że najbardziej adekwatny obraz samego siebie prezentowali uczniowie z klas ruchomych. Sytuacja, w jakiej wypełniali oni swoje zadania edukacyjne, stwarzała możliwość dostrzegania zarówno własnych odmienności, jak i podobieństw, pozwalała weryfikować indywidualne zasoby, nie wykluczając możliwości odniesienia sukcesu. Uzyskany rezultat badawczy upoważnia do stwierdzenia, że niekorzystną dla rozwoju jest zarówno sytuacja, w której jednostka czuje się najsłabsza, zdominowana przez innych, jak i taka, która pozwala przyjąć pozycję górowania nad innymi, nie dostrzegania swoich słabości.

Nieprawidłowość samooceny przejawianej przez osoby z diagnozą upośledzenia umysłowego $\mathrm{w}$ stopniu lekkim została udokumentowana $\mathrm{w}$ wielu badaniach naukowych [Różycka 1959; Kościelak 1989; Pilecka 2000; Olszewski 1995; Janiszewska-Nieścioruk 1999]. Należy zaznaczyć, że bezpośrednim źródłem zaburzonej samooceny nie jest niższy potencjał intelektualny, lecz doświadczanie dezaprobaty społecznej. Sposób traktowania osób niepełnosprawnych intelektualnie, wymagania i zadania stawiane przed nimi, role społeczne i zawodowe im przypisywane to istotne czynniki wpływające na kształtowanie obrazu samego siebie. Jedni badacze wskazują, że osoby z niepełnosprawnością intelektualną lekkiego stopnia ujawniają zawyżoną samoocenę, inni natomiast wskazują na samoocenę zaniżoną [zob. Pilecka 2000]. O ile skutkiem zawyżonej samooceny może być podejmowanie działań przewyższających faktyczne możliwości ucznia, to zaniżona samoocena będzie prowadziła do bierności i unikania działań na miarę rzeczywistych możliwości. Zarówno w jednym, jak i w drugim przypadku należy liczyć się z brakiem sukcesów, mobilizujących do podejmowania kolejnych wyzwań i pozwalających budować pozytywny wizerunek własny.

Z całą pewnością uzyskanie orzeczenie o potrzebie kształcenia specjalnego to istotny punkt w życiorysie dziecka. Dokument ten ma swoistą "moc sprawczą", kształtując pozycję ucznia w przestrzeni edukacyjnej, wciągając go w wir specyficznych, narzuconych zewnętrznie zdarzeń. Orzeczenie jest dokumentem, który w założeniu ma umożliwić uczestnictwo w normalnym biegu życia, lecz niejednokrotnie wytrąca z tego biegu i spycha na boczne tory. 


\section{Klasa zerowa - przygotowanie do równego startu edukacyjnego}

Od 1 września 2004 roku każde dziecko przed rozpoczęciem edukacji w klasie pierwszej szkoły podstawowej jest zobowiązane odbyć roczne przygotowanie przedszkolne. Biorąc pod uwagę fakt, że wiele dzieci wzrasta w niekorzystnych warunkach uniemożliwiających opanowanie koniecznych wiadomości, umiejętności i nawyków, wprowadzenie rocznego przygotowania do nauki szkolnej należy uznać za trafne rozwiązanie pozwalające wspomóc psychospołeczny rozwój dziecka. W założeniu zajęcia prowadzone w klasie zerowej mają wyrównywać start edukacyjny, minimalizować ujawnione trudności, umożliwiając dzieciom podjęcie skutecznej edukacji. Nie sposób stwierdzić, w jakim stopniu zakładane zadania są realizowane w rzeczywistości. Już przed ponad trzydziestu laty Małgorzata Kościelska [1984, s. 100] postawiła pytanie o wpływ klas zerowych na funkcjonowanie dziecka oraz ich udział w wyrównywaniu szans rozwojowych. Autorka nie wyklucza, że klasy te zamiast realizować działania korekcyjno-wyrównawcze, imitują system szkolny, stawiając przed dziećmi wymagania niemożliwe do spełnienia. Istotność problemu i brak wiarygodnych informacji sugeruje potrzebę podjęcia badań w tym zakresie.

Oczekiwania stawiane wobec klas zerowych muszą mieć znamiona realności. Trzeba być świadomym, że w przypadku poważnych braków i zaburzeń rozwojowych w ciągu roku nie wyeliminuje się konsekwencji wcześniejszych zaniedbań. Okres najintensywniejszego rozwoju, pozwalający osiągnąć trzecią część zdolności poznawczych człowieka, przypada bowiem na pierwszych sześć lat życia [R.S. Bloom, za: Głodkowska 1999, s. 7]. W przypadku wielu dzieci lata te zostały bezpowrotnie zaprzepaszczone. Nastąpiło zahamowanie rozwoju, pojawiły się braki, które trudno wyrównać i które będą dawały znać o sobie w kolejnych latach edukacji. Wprawdzie rozwiązania systemowe w naszym kraju pozwalają objąć działaniami pomocowymi dzieci o zaburzonym rozwoju od chwili urodzenia do momentu podjęcia edukacji szkolnej, to jednak w przypadku dzieci zagrożonych niepełnosprawnością intelektualną w stopniu lekkim, rozwiązanie to nie jest szeroko stosowane. Powodem takiego stanu rzeczy może być brak orientacji w zakresie braków i trudności rozwojowych dziecka, a także brak wiedzy rodziców na temat systemowych działań pomocowych. Dodatkową trudność mogą stwarzać biurokratyczne procedury. Ponadto we wczesnym okresie życia dziecka nieprawidłowości i zaburzenia rozwojowe mogą nie być wyraźnie widoczne. To właśnie etap klasy zerowej jest okresem, w którym opiekunowie dzieci zagrożonych niepełnosprawnością intelektualną lekkiego stopnia uzyskują pierwsze informacje o niedoskonałościach rozwojowych dziecka i potrzebie zastosowania działań o charakterze korekcyjnym, wspomagających psychofizyczny rozwój. 
Dzieci, wobec których nie zostaną zastosowane odpowiednie rozwiązania pomocowe, bądź te, u których występują braki rozwojowe niemożliwe do skorygowania w czasie rocznego przygotowania do nauki, podejmą edukację w klasie pierwszej z nikłą szansą na sprostanie wymaganiom programowym.

Niektóre spośród dzieci, na skutek ujawnianych trudności uniemożliwiających uzyskanie wymaganego poziomu dojrzałości szkolnej, korzystają z prawa do odroczenia od obowiązku szkolnego i z rocznym opóźnieniem podejmują naukę w klasie pierwszej. Należy jednak wyraźnie podkreślić, że opóźnienie $\mathrm{w}$ rozpoczęciu edukacji szkolnej nie przesądza o tym, że mamy do czynienia z uczniem, który w przyszłości uzyska orzeczenie o niepełnosprawności intelektualnej. Brak umiejętności wymaganych na starcie edukacyjnym może być spowodowany nie tylko na tyle niskim poziomem sprawności intelektualnej, który upoważnia do orzekania o niepełnosprawności intelektualnej, ale również może dotyczyć osób charakteryzujących się wolniejszym tempem lub zahamowaniem rozwojowym, słabym stanem zdrowia utrudniającym opanowanie określonych sprawności, czy też może być diagnozowany u tych dzieci, które urodziły się w końcowych miesiącach roku kalendarzowego i z tej racji nie są w stanie zadośćuczynić wymaganiom stawianym przed uczniem klasy pierwszej.

Badanie pod kątem dojrzałości szkolnej w poradni psychologiczno-pedagogicznej, która jest uprawniona do orzekania o potrzebie odroczenia obowiązku szkolnego, odbywa się wyłącznie na wniosek prawnych opiekunów dziecka. Rodzice, którzy bagatelizują sprawy dziecka, obojętnie odnoszą się do jego problemów i nie angażują się w jego edukację, zapewne nie skorzystają z możliwości badań diagnostycznych. Okazuje się, że w grupie uczniów z niepełnosprawnością intelektualną w stopniu lekkim z prawa od odroczenia od obowiązku szkolnego korzystają zazwyczaj dzieci, których opiekunowie wyróżniają się pozytywnie pod względem statusu zawodowego i społecznego [zob. Parys, Olszewski 2003; Sadownik 2011].

\section{Start edukacyjny - pozornie równy}

Zdecydowana większość dzieci z niepełnosprawnością intelektualną w stopniu lekkim podejmuje start edukacyjny w szkołach ogólnodostępnych, według powszechnie obowiązujących zasad, bez specjalnego prawa do ułatwień i udogodnień. Dzieje się tak, ponieważ rozpoczynając edukację uczniowie ci zazwyczaj nie posiadają jeszcze orzeczenia o niepełnosprawności i potrzebie kształcenia specjalnego. Tymczasem, jak stwierdza Joanna Głodkowska [1999], znaczna część dzieci z lekką niepełnosprawnością intelektualną rozpoczynając pierwszy etap 
edukacyjny nie osiąga takiego poziomu dojrzałości szkolnej, który umożliwia samodzielne konstruowanie wymaganych strategii umysłowych pozwalających poznawać świat, podejmować i efektywnie realizować zadania szkolne. „Okres wczesnoszkolny dla dziecka upośledzonego umysłowo w stopniu lekkim to w kategoriach jego możliwości rozwojowych wiek przedszkolny dziecka w normie intelektualnej" [Głodkowska 1999, s. 37]. Pomimo zaburzeń w funkcjonowaniu orientacyjno-poznawczym i braku umiejętności wykonawczych, dzieci te wykazują jednak zainteresowanie działaniami szkolnymi i w miarę możliwości reagują na sygnały pedagogiczne. Lapidarnie stwierdzając, uczniowie niepełnosprawni intelektualnie w stopniu lekkim na progu edukacji prezentują wobec zadań szkolnych postawę "bardziej chcę niż potrafię" [zob. Głodkowska 1999, s. 119]. Nawiązując do teorii Stefana Szumana, stan charakteryzujący się przejawami zainteresowania wobec aktywności szkolnych i równoczesnym brakiem gotowości do samodzielnej, skutecznej pracy, Joanna Głodkowska ${ }^{4}$ [1999] nazywa wrażliwością edukacyjną. Wrażliwość ta jest zarówno wskaźnikiem możliwości, jak i trudności dziecka.

Poruszając problem orzecznictwa o niepełnosprawności intelektualnej, wspomniałam, że opiekunowie wielu uczniów długo zwlekają ze złożeniem $\mathrm{w}$ poradni psychologiczno-pedagogicznej wniosku o podjęcie odpowiednich działań diagnostycznych. Zdarza się również, że po uzyskaniu stosownych orzeczeń nie ujawniają ich w placówce edukacyjnej, sprawia to, że wobec dziecka nie można zastosować rozwiązań kształcenia specjalnego. Bardzo często ostatecznym czynnikiem, który doprowadza do tego, że rodzice decydują się na badania diagnostyczne w poradni psychologiczno-pedagogicznej i ujawniają ich rezultat pedagogom, są narastające trudności edukacyjne dziecka, zagrożenie drugorocznością, a także niska szansa na ukończenie szkoły z pozytywnym wynikiem. W przypadku uczniów, u których odpowiednio wcześnie nie zostały rozpoznane trudności i zaburzenia, którym nie udzielono właściwego wsparcia psychopedagogicznego, można mówić o zaprzepaszczeniu pierwszych lat edukacyjnych. Z punktu widzenia przebiegu edukacji i stymulacji rozwoju są to lata "puste" [Kościelska 1984, s. 103]. Poza stratami w funkcjonowaniu poznawczym, trzeba liczyć się również z niekorzystnymi konsekwencjami w kształtowaniu osobowości. Dziecko, które nie mogło podołać wymaganiom szkolnym, zapewne doświadczało niepowodzeń i frustracji, nabywało i utrwalało przekonanie o konieczności doznawania porażek szkolnych i braku możliwości odniesienia sukcesu,

Autorka nie ograniczyła się do rozważań teoretycznych, lecz opracowała narzędzie diagnostyczne, które pozwala nauczycielowi zdobyć orientację edukacyjną w zakresie zdolności szkolnych ucznia, trafnie ocenić jego poziom wrażliwości edukacyjnej, a w rezultacie umożliwia planowanie działań rehabilitacyjnych, zmierzających do ograniczenia trudności, wyrównania braków i wzmocnienia zasobów dziecka wchodzącego w rolę ucznia. 
podejmowało bezproduktywny wysiłek, by w rezultacie utracić motywację do nauki szkolnej.

Analizując sytuację edukacyjną, w jakiej znajdują się dzieci niepełnosprawne intelektualnie w pierwszych latach nauki, Małgorzata Kościelska [1984, s. 101] stawia pytanie: „czy nie słuszniej byłoby mówić o nich - zamiast jako o dzieciach upośledzonych umysłowo - jako o dzieciach upośledzonych pod względem edukacyjnym?" Propozycja ta wydaje się o tyle słuszna, że to właśnie w obliczu wymagań szkolnych zostaje ujawniona niepełnosprawność, a uzyskane orzeczenie jest wystawione wyłącznie dla potrzeb edukacyjnych i w systemie pozaszkolnym nie ma żadnego znaczenia.

\section{Kształcenie specjalne - wielość dróg}

Uczniowie niepełnosprawni intelektualnie w stopniu lekkim są rozpoznawani i kwalifikowani do kształcenia specjalnego w różnym wieku życia, na różnych etapach drogi edukacyjnej. Są wśród nich tacy, którzy już od pierwszego etapu edukacyjnego funkcjonują w roli ucznia niepełnosprawnego, ale bywa i tak, że status ten uzyskują dopiero na poziomie szkoły zawodowej. Im później uczeń trafia $w$ tryby kształcenia specjalnego, tym bardziej złożone, pełne nieszczęśliwych zbiegów okoliczności są jego doświadczenia szkolne [zob. Sadownik 2011]. To co łączy wszystkich uczniów rozpoczynających edukację w szkole ogólnodostępnej i dopiero w miarę upływu czasu uzyskujących orzeczenie o potrzebie kształcenia specjalnego, to brak sukcesów edukacyjnych, liczne porażki i niepowodzenia wyrażające się negatywnymi ocenami, a czasami również koniecznością powtarzania klasy. Niepowodzenia szkolne wrastają w poprzek uczniowskich biografii i determinują ich dalsze losy edukacyjne [Kwieciński 2002]. Sytuacja ta budzi niepokój i sprzeciw, jeśli weźmiemy pod uwagę fakt, że wiele uczniów nie otrzymuje odpowiedniej pomocy psychologiczno-pedagogicznej na terenie macierzystej placówki edukacyjnej [Prawa osób z niepetnosprawnościa intelektualnq..., 2005, s. 58], a nauczyciele zobowiązani do udzielenia wsparcia wykazują biernośći obojętność wobec uczniowskich potrzeb [zob. Sadownik 2011].

Proces nauczycielskich działań wspierających może opierać się na podejściu typu „mój uczeń ma problem, chcę mu pomóc", lub przekonaniu ,ja mam problem z uczniem, muszę go rozwiązać" [zob. Brzezińska, Ohme, Resler-Maj, Kaczan, Wiliński 2009, s. 16-17]. Pierwszy sposób myślenia mobilizuje do poszukiwania rozwiązań uwzględniających indywidualne potrzeby i możliwości dziecka, pozwalających zapewnić mu samodzielność działania. Natomiast drugie przeświadczenie ukazuje niepełnosprawność jako źródło trudności dla otoczenia, skłaniając 
do poszukiwania i wdrażania działań, które pozwolą wyeliminować napotykane trudności, niekoniecznie uwzględniając faktyczne potrzeby i możliwości rozwojowe ucznia niepełnosprawnego.

W polskim systemie edukacyjnym kształcenie specjalne, które według założeń polega na odpowiednim dopasowaniu zadań edukacyjnych do psychofizycznych możliwości ucznia niepełnosprawnego, jest realizowane przy zastosowaniu modelu wielu ścieżek. Ustawa z dnia 7 września 1991 r. o systemie oświaty [Dz. U. z 1991 r. Nr 95, poz. 425] zapewnia dzieciom i młodzieży niepełnosprawnej możliwość pobierania nauki we wszystkich typach szkól, zgodnie z indywidualnymi potrzebami rozwojowymi i edukacyjnymi oraz predyspozycjami. Przykładem nadużycia, wskazującym na stosowanie przemocy są przypadki, w których pojawiają się „próby wywierania nacisku przez władze samorządowe na poradnie psychologiczno-pedagogiczne, by $\mathrm{w}$ orzeczeniach zawierały zalecenia zgodnie $\mathrm{z}$ aktualnie istniejącymi $\mathrm{w}$ powiecie placówkami, co niekoniecznie zawsze odpowiada rzeczywistym potrzebom dziecka" [Prawa osób z niepetnosprawnościq intelektualna... 2005, s. 49]. Ostateczna decyzja co do wyboru drogi edukacyjnej dla dziecka posiadającego orzeczenie o potrzebie kształcenia specjalnego leży w gestii prawnych opiekunów, którzy mogą kierować się zaleceniami zawartymi w orzeczeniu, wystawionym przez poradnię psychologiczno-pedagogiczną, lecz nie są zobowiązani bezwzględnie do ich przestrzegania.

Coraz częściej wybierając miejsce edukacji niepełnosprawnego dziecka rodzice wskazują placówkę o charakterze integracyjnym. Decydując się na tę formę kształcenia, kierują się zarówno przesłankami pozytywnymi, jak i negatywnymi [zob. Sadowska 2005; Grzyb 2013]. Opiekunowie mają nadzieję, że nauka razem z pełnosprawnymi rówieśnikami będzie sprzyjała rozwojowi dziecka, pozytywnie wpłynie na jakość jego funkcjonowania psychospołecznego. Innym czynnikiem, warunkującym wybór placówki integracyjnej, może być pejoratywne nastawienie wobec szkoły specjalnej, chęć chronienia dziecka przed środowiskiem, które negatywnie naznacza, nie cieszy się uznaniem społecznym. Niebagatelne znaczenie dla podejmowanej decyzji ma również lokalizacja placówki, jej bliskość od miejsca zamieszkania.

Przekonania, którymi kierują się rodzice wybierając placówkę edukacyjną, pod wpływem doświadczeń szkolnych dziecka niejednokrotnie ulegają zmianie. Z dotychczasowych badań [Bobeł 2003; Minczakiewicz 2003] wynika, że większość rodziców decydujących się na edukację dziecka w placówce integracyjnej wyraża niezadowolenie z warunków, przebiegu i efektów kształcenia, natomiast wśród rodziców wybierających szkołę specjalną dominuje poczucie zadowolenia. Informacji tej nie można jednak traktować jako wskaźnika świadczącego o lepszej jakości kształcenia w warunkach szkoły specjalnej. Sławomira Sadowska [2006b] wysuwa przypuszczenie, że odmienność ocen obydwu placówek wynika ze zróż- 
nicowanych oczekiwań rodziców wybierających szkołę integracyjną lub specjalną jako miejsce edukacji swojego dziecka. Prawdopodobnie jedna i druga grupa rodziców inaczej postrzega miejsce i rolę szkoły w życiu dziecka i rodziny, przypisuje jej inny zakres zadań. Domniemanie to wydaje się tym bardziej słuszne, jeśli uwzględnimy fakt, że pomiędzy sytuacją rodzinną a miejscem edukacji dziecka z niepełnosprawnością intelektualną $\mathrm{w}$ stopniu lekkim występuje widoczna zależność. Rodzice dzieci ze szkół integracyjnych, w porównaniu z rodzicami uczniów szkół specjalnych, charakteryzują się wyższym statusem społeczno-ekonomicznym, wykazują większe zainteresowanie edukacją dzieci, chętniej współpracują ze szkołą, wcześniej decydują się na podjęcie działań diagnostycznych i korekcyjno-kompensacyjnych [Parys, Olszewski 2003; Gebreselassie 2011; Sadownik 2011]. Sytuacja ta może sugerować, że rodzice wybierający integracyjne formy kształcenia z większym zaangażowaniem kształtują drogę edukacyjną swojego dziecka. Nie oznacza to jednak, że dokonując wyboru placówki edukacyjnej, opierają się na określonych wizjach i oczekiwaniach.

Jak wcześniej zasygnalizowałam, wybór miejsca edukacji dziecka może być wynikiem odmiennych potrzeb, a w przypadku rodziców decydujących się na szkołę specjalną może również opierać się na wcześniejszych doświadczeniach. Trzeba zauważyć, że kształcenie w szkole specjalnej wielu dzieci z tej samej rodziny, a także kolejnych pokoleń, nie jest zjawiskiem należącym do rzadkości. Kontynuacja współpracy ze szkołą specjalną może być dowodem zadowolenia i spełnienia oczekiwań rodziców, ale także być wynikiem przekonania, że szkoła specjalna na trwałe wpisuje się w doświadczenia rodziny, a inne miejsca edukacji tylko pozornie są dostępne dziecku, bowiem wiążą się z nimi wyzwania, które mogą przysporzyć rodzinie trudności niemożliwych do rozwiązania.

Zjawiskiem, które należy uwzględnić rozważając losy edukacyjne uczniów z niepełnosprawnością, jest niedopasowanie formy kształcenia do potrzeb i możliwości psychospołecznego funkcjonowania dziecka. Zarówno w szkołach masowych są uczniowie, dla których bardziej odpowiednim miejscem byłyby placówki specjalne, jak i w szkołach specjalnych są tacy, którzy bez trudności mogliby podołać wymaganiom stawianym w placówkach kształcenia integracyjnego. Dowodem niewłaściwych wyborów miejsca edukacji dla ucznia niepełnosprawnego intelektualnie jest zjawisko rekwalifikacji uczniów ze szkół integracyjnych do specjalnych. Uczniowie z niepełnosprawnością intelektualną w stopniu lekkim w różnym okresie nauki „wypadają” z integracyjnych form kształcenia, szczególnie często zjawisko to daje znać o sobie na wyższych etapach edukacyjnych [zob. Prawa osób z niepetnosprawnościa intelektualną..., 2005, s. 69; Sadownik 2011, s. 10; Grzyb 2013, s. 119; Hołub 2017, s. 35]. W efekcie, im wyższy etap edukacji, tym większy odsetek uczniów z niepełnosprawnością kształci się w szkołach specjalnych [Chrzanowska 2010, s. 44]. Zmianę miejsca edukacji z placówki ogólnodostęp- 
nej lub integracyjnej na placówkę specjalną należy w kontekście założeń edukacji włączającej traktować jako porażkę i przejaw niewydolności systemu edukacyjnego. Rozwiązaniem wskazującym na skuteczność oddziaływań rehabilitacyjnych jest przechodzenie dziecka od segregacyjnych form nauczania ku formom integracyjnym. Założenie tego rodzaju opisał na przykładzie kanadyjskiego modelu kształcenia integracyjnego Jean P. Moulin [1996, s. 27]. Model ten, zwany modelem kaskadowym, uwzględnia osiem poziomów: od pierwszego, w którym uczeń niepełnosprawny uczęszcza do klasy ogólnodostępnej, do ósmego respektującego kształcenie w szkole specjalnej. Jedynie w ekstremalnych warunkach dopuszcza się ruch w kierunku przeciwnym od zakładanego, tj. od poziomu ósmego do pierwszego. W polskiej rzeczywistości, pomimo że przepisy prawa oświatowego stwarzają uczniom możliwość przejścia ze szkoły specjalnej do szkoły ogólnodostępnej, w praktyce sytuacje takie zdarzają się niezwykle rzadko [Prawa osób z niepetnosprawnościa intelektualnq..., 2005, s. 17].

Podmiotowy i emancypacyjny paradygmat pedagogiki specjalnej zmusza do poszukiwania odpowiedzi na pytania: Czy uczniowie z niepełnosprawnością intelektualną w stopniu lekkim mają wpływ na kształtowanie swej drogi edukacyjnej? W jakim stopniu rodzice decydując o losie edukacyjnym swego dziecka kierują się własnymi sądami, potrzebami i oczekiwaniami, a w jakim uwzględniają stanowisko dziecka, jego faktyczne potrzeby i możliwości? Jak uczniowie z niepełnosprawnością intelektualną $\mathrm{w}$ stopniu lekkim postrzegają własną sytuację edukacyjną? W stosunku do dwóch pierwszych pytań nie sposób udzielić miarodajnej odpowiedzi, ponieważ brakuje badań z tego zakresu. Można jedynie przypuszczać, że głos ucznia niepełnosprawnego nie jest brany pod uwagę przy wyborze formy kształcenia, zaś wolność wyboru jest sprowadzona wyłącznie do wolności wyboru rodziców [zob. Gołubiew, Krause 2007, s. 84]. Odpowiadając natomiast na pytanie dotyczące percepcji własnej sytuacji edukacyjnej uczniów z niepełnosprawnością intelektualną w stopniu lekkim można odwołać się do wyników badań realizowanych w różnym czasie przez kolejnych autorów.

Uczniowie, którzy trafiają do szkół specjalnych z placówek ogólnodostępnych, swoją sytuację edukacyjną oceniają w różny sposób. Są wśród nich tacy, którzy wyrażają zadowolenie z realizacji nauki w szkole specjalnej, jak i tacy, którzy nie akceptują szkoły specjalnej i mają poczucie krzywdy wynikającej z konieczności uczęszczania do tej placówki. Małgorzata Kościelska [1984] ustaliła, że uczniowie szkoły specjalnej najczęściej wśród powodów zadowolenia zgłaszają: odpowiednie dostosowanie wymagań edukacyjnych, fakt doświadczania sukcesów szkolnych, a także dobre kontakty z nauczycielami. Natomiast czynnikami budzącymi niechęć wobec szkoły specjalnej są złe relacje rówieśnicze, świadomość niskiego statusu szkoły w percepcji społecznej, przekonanie o ograniczeniu perspektyw życiowych. Poza uczniami, którzy w jednoznaczny sposób oceniają 
swoje miejsce edukacji, można wskazać również osoby, które wyrażają ambiwalentny stosunek do szkoły specjalnej. Traktują ją jako środowisko zarówno obciążające, jak i wyzwalające.

Alicja Sadownik [2011, s. 108] wskazuje, że w przypadku uczniów, którzy wcześnie zostali zdiagnozowani i już na pierwszym etapie kształcenia przeszli ze szkoły ogólnodostępnej do specjalnej, można mówić o doświadczeniu poczucia ulgi i ukojenia. Zmiana miejsca edukacji pozwoliła wyrwać się ze środowiska, w którym czuli się zagubieni i nieakceptowani, a następnie wejść w środowisko, uwzględniające ich potrzeby i możliwości. Inaczej rzecz traktują uczniowie, którzy w struktury szkoły specjalnej przeszli na wyższych etapach edukacyjnych. Większość z nich negatywnie postrzega konieczność zmiany miejsca kształcenia, a także sposób funkcjonowania, ofertę edukacyjną i wizerunek społeczny szkoły specjalnej. Prezentują oni przekonanie, że diagnoza, którą uzyskali, jest niesprawiedliwa, krzywdząca i naznaczająca, a także ograniczająca możliwości życiowe i narzucająca poślednie role i miejsce w społeczeństwie. Również uczniowie badani przez Katarzynę Materny [2005] twierdzą, iż edukacja w szkole specjalnej jest ogranicznikiem dalszych perspektyw życiowych. Są oni przekonani, że lepszy start w przyszłość zapewnia nauka w szkole ogólnodostępnej.

Badania Sławomiry Sadowskiej [2006a] wskazują, iż uczniowie z placówek kształcenia integracyjnego, w porównaniu z uczniami z placówek specjalnych, wyrażają wyższy ogólny poziom zadowolenia ze szkoły. Należy jednak zwrócić uwagę, że w wielu cząstkowych wymiarach (poziom trudności zadań, tempo pracy, możliwość aktywnego uczestnictwa w działaniach szkolnych), to właśnie uczniowie szkoły specjalnej wyrażali wyższy poziom zadowolenia. Zaistniały paradoks Sadowska [2006a] tłumaczy tym, że pomimo doświadczania korzystnych warunków rozwojowych w szkole specjalnej uczniowie mają świadomość, że placówki tego rodzaju nie cieszą się uznaniem i aprobatą społeczną, lecz są nisko oceniane przez otoczenie społeczne. Naznaczająca ocena społeczna staje się dla uczniów ważniejsza od faktu funkcjonowania w środowisku, które respektuje ich potrzeby i możliwości edukacyjne. Społeczne piętno powoduje, że uczniowie wstydzą się szkoły specjalnej i niejednokrotnie próbują zataić fakt uczęszczania do niej [Materny 2005; Sadownik 2011].

Przyjmując, że edukacja integracyjna jest predykatorem przyszłego funkcjonowania w środowisku ludzi pełnosprawnych, Amadeusz Krause [2005] stwierdza, iż uczniowie niepełnosprawni w zespole integracyjnym doświadczają „„dylematu szczęścia". Na etapie edukacji doznają pozorów integracji, godzą się z odrzuceniem, społeczną izolacją, upokorzeniem, w nadziei, iż w przyszłości zostaną włączeni w życie społeczne. Anders Gustavsson [1997, s. 183] dostrzega, że pomimo negatywnych doświadczeń zgromadzonych w szkole integracyjnej, osoby niepełnosprawne wyrażają silne przeświadczenie o prawie do społecznej 
akceptacji na równi z innymi. Przywołany autor formułuje przypuszczenie, że źródłem tego przekonania jest przynależność do subkultury integracji. To właśnie środowiska promujące hasła integracji i normalizacji, w których wzrastały osoby niepełnosprawne, stawały się obroną przed stygmatyzacją.

Ważną kwestią dotyczącą wielu uczniów korzystających z kształcenia specjalnego jest złamanie normalizacyjnej zasady życiorysu, wynikające z konieczności funkcjonowania $\mathrm{w}$ środowisku nierówieśniczym, nietożsamym wiekowo [Gołubiew-Konieczna 2012, s. 31]. Wskutek różnych doświadczeń (odroczenie od obowiązku nauki, brak promocji do kolejnej klasy, wydłużenie etapu edukacyjnego) uczniowie z niepełnosprawnością intelektualną często wyprzedają wiekiem swoich kolegów klasowych. W takiej sytuacji istnieje niebezpieczeństwo wtórnego upośledzania polegające na tym, iż uczeń jest poddawany oddziaływaniom, które uwzględniają jego poziom funkcjonowania poznawczego, natomiast całkowicie pomijają wiek życia. Zjawisko to Amadeusz Krause [2004, s. 228] nazywa infantylizacją procesu rewalidacyjnego.

\section{Kształcenie zawodowe - dla czy obok potrzeb rynku pracy?}

Podobnie jak w przypadku placówek, w których uczeń realizuje obowiązek szkolny, tak i na kolejnych etapach kształcenia uczeń niepełnosprawny intelektualnie w stopniu lekkim może kontynuować naukę w placówkach ogólnodostępnych, integracyjnych lub specjalnych. Najczęściej kształcenie przygotowujące do pracy zawodowej jest realizowane w zasadniczych szkołach zawodowych specjalnych. Ten typ placówki wybierają zarówno absolwenci gimnazjów specjalnych, jak i uczniowie, którzy wcześniej korzystali z integracyjnych form edukacji [zob. Chrzanowska 2010; Grzyb 2011; Sadownik 2011]. Wybór ten nie wydaje się być trafny, może być powodem dalszych trudności, gdyż pracodawcy niechętnie zatrudniają osoby z wykształceniem specjalnym [Giermanowska 2007, s. 183].

Lista zawodów nauczanych $\mathrm{w}$ systemie szkolnym (tzw. zawody szkolne), w ramach których można podjąć kształcenie w zasadniczej szkole zawodowej specjalnej, jest określona w klasyfikacji zawodów szkolnictwa zawodowego. Jest to podstawowy dokument prawny regulujący zakres kształcenia zawodowego w Polsce. Obecnie obowiązującym dokumentem jest rozporządzenie MEN z dnia 13 grudnia 2016 roku w sprawie klasyfikacji zawodów szkolnictwa zawodowego [Dz. U. z 2016 r., poz. 2094], natomiast od 1 września 2017 roku wejdzie w życie rozporządzenie z dnia 13 marca 2017 roku [Dz. U. z 2017 r., poz. 622]. Poza zawodami robotniczymi, które są dostępne dla wszystkich uczniów podejmujących naukę w zasadniczej szkole zawodowej, rozporządzenia przewidują zawody do- 
stępne wyłącznie dla uczniów z niepełnosprawnością intelektualną w stopniu lekkim. W 2004 roku po raz pierwszy w klasyfikacji zawodów szkolnictwa zawodowego [Dz. U. z 2004 r. Nr 114, poz. 1195] umieszczono zawód dedykowanym wyłącznie dla uczniów z niepełnosprawnością intelektualną w stopniu lekkim, tj. pracownik pomocniczy obsługi hotelowej. Najnowsze rozporządzenie wchodzące w życie z dniem 1 września 2017 roku [Dz. U. z 2017 r., poz. 622] przewiduje wprowadzenie kolejnych zawodów, w których na poziomie szkoły branżowej pierwszego stopnia będą mogli kształcić się wyłącznie uczniowie z lekką niepełnosprawnością intelektualną. Wykaz tych zawodów wraz z podstawowymi charakterystykami zamieszczono w tabeli 1 .

Tabela 1. Zawody przeznaczone do kształcenia wyłącznie dla osób z niepełnosprawnością intelektualną w stopniu lekkim na poziomie szkoły branżowej pierwszego stopnia (Dz. U. z 2017 r., poz. 622)

\begin{tabular}{|l|l|l|}
\hline \multicolumn{1}{|c|}{$\begin{array}{c}\text { Nazwa zawodu wraz } \\
\text { z symbolem cyfrowym }\end{array}$} & \multicolumn{1}{|c|}{ Obszar kształcenia } & \multicolumn{1}{|c|}{$\begin{array}{c}\text { Nazwa kwalifikacji wyodrębnionych } \\
\text { w zawodzie }\end{array}$} \\
\hline $\begin{array}{l}\text { Pracownik pomocniczy } \\
\text { obsługi hotelowej } \\
\text { (911 205) }\end{array}$ & $\begin{array}{l}\text { Turystyczno-gastronomiczny } \\
\text { (TG) }\end{array}$ & $\begin{array}{l}\text { Wykonywanie prac pomocniczych } \\
\text { w obiektach świadczących usługi } \\
\text { hotelarskie. }\end{array}$ \\
\hline $\begin{array}{l}\text { Pracownik pomocniczy } \\
\text { krawca (932 915) }\end{array}$ & $\begin{array}{l}\text { Administracyjno-usługowy } \\
\text { (AU) }\end{array}$ & $\begin{array}{l}\text { Projektowanie i wytwarzanie prostych } \\
\text { wyrobów odzieżowych. }\end{array}$ \\
\hline $\begin{array}{l}\text { Pracownik pomocniczy } \\
\text { mechanika (932 916) }\end{array}$ & $\begin{array}{l}\text { Mechaniczny i górniczo- } \\
\text {-hutniczy (MG) }\end{array}$ & $\begin{array}{l}\text { Montaż i obsługa prostych maszyn } \\
\text { i urządzeń. }\end{array}$ \\
\hline $\begin{array}{l}\text { Pracownik pomocniczy } \\
\text { ślusarza (932 917) }\end{array}$ & $\begin{array}{l}\text { Mechaniczny i górniczo- } \\
\text {-hutniczy (MG) }\end{array}$ & $\begin{array}{l}\text { Wykonywanie i naprawa elementów } \\
\text { prostych, maszyn, urządzeń i narzędzi }\end{array}$ \\
\hline $\begin{array}{l}\text { Pracownik pomocniczy } \\
\text { stolarza (932 918) }\end{array}$ & $\begin{array}{l}\text { Administracyjno-usługowy } \\
\text { (AU) }\end{array}$ & $\begin{array}{l}\text { Wytwarzanie prostych wyrobów } \\
\text { stolarskich. }\end{array}$ \\
\hline $\begin{array}{l}\text { Asystent fryzjera } \\
\text { (932 919) }\end{array}$ & $\begin{array}{l}\text { Administracyjno-usługowy } \\
\text { (AU) }\end{array}$ & $\begin{array}{l}\text { Wykonywanie prostych zabiegów } \\
\text { fryzjerskich. }\end{array}$ \\
\hline
\end{tabular}

Źródło: Opracowanie własne.

Wszystkie zawody dedykowane osobom z niepełnosprawnością intelektualną w stopniu lekkim należą do grupy nazwanej Pracownicy wykonujący prace proste. Zawody te są zawodami jednokwalifikacyjnymi

Zasadnicze szkoły zawodowe specjalne często nie są przystosowane do oczekiwań rynku pracy [Prawa osób z niepetnosprawnościq intelektualna..., 2005, s. 84; Hołub 2017, s. 35]. Kształceniu, które ma przygotować uczniów z niepełnosprawnością intelektualną $\mathrm{w}$ stopniu lekkim do podjęcia pracy zawodowej, zarzuca się niską jakość, sprawia to, iż absolwenci mają trudność w znalezieniu miejsca na rynku pracy [Prawa osób z niepetnosprawnościq intelektualną..., 2005, s. 126; Chrzanowska 2010, s. 140-141]. Pod adresem oferty kształcenia proponowanej w zasadni- 
czych szkołach zawodowych specjalnych kierowane są uwagi, iż nie uwzględnia ona potrzeb pracodawców, a także możliwości psychofizycznych uczniów z niepełnosprawnością intelektualną. Inne niedoskonałości kształcenia w zasadniczych szkołach zawodowych specjalnych to niski poziom praktyk bądź ich niewielki zakres, brak nowoczesnej infrastruktury czy, niedobór wykwalifikowanej kadry nauczycielskiej [Otrębski 2001, 2007; Hołub 2017].

Niedoskonałość funkcjonowania zawodowej szkoły specjalnej ujawnia w swym opracowaniu Alicja Sadownik [2011]. Rekonstruując codzienne życie uczniów pokazuje w jaki sposób zawodowa szkoła specjalna „staje się przestrzenią studzącą aspiracje uczniów, lekceważącą ich edukację zawodową, pozbawiającą realnych szans na zdobycie zatrudnienia oraz wspierającą praktyczne umiejętności korzystania ze świadczeń socjalnych" [Sadownik 2011, s. 322]. Na podstawie zgromadzonego materiału badawczego wspomniana autorka stwierdza, że: „W trakcie długiego pobytu w szkole specjalnej uczniowie oswajają się ze specjalną pozycją społeczną, z perspektywą życia finansowanego ze świadczeń socjalnych i wizją siebie jako osoby bezrobotnej (ale szczęśliwej)" [Sadownik 2011, s. 172].

Potwierdzeniem kwalifikacji uzyskanych podczas kształcenia w zasadniczej szkole zawodowej specjalnej jest zewnętrzny egzamin zawodowy, obejmujący etap pisemny i praktyczny [Rozporządzenie MEN z dnia 27 kwietnia $2015 \mathrm{r}$. w sprawie szczegółowych warunków i sposobu przeprowadzania egzaminu potwierdzającego kwalifikacje w zawodzie, Dz. U. z 2015 r., poz. 673]. Egzamin ten jest przeprowadzany zgodnie ze standardami wymagań, opracowanymi przez CKE. Sposoby i warunki dostosowania egzaminów zawodowych do potrzeb i możliwości uczniów ujawniających specjalne potrzeby edukacyjne zostały określone w komunikacie dyrektora CKE [www.cke.edu.pl/images/_KOMUNIKATY/Komunikat\%20o\%20dostosowaniach\%202016-2017.pdf].

$\mathrm{Na}$ podstawie orzeczenia o potrzebie kształcenia specjalnego, uczeń z niepełnosprawnością intelektualną $\mathrm{w}$ stopniu lekkim w trakcie egzaminu może korzystać ze sprzętu specjalistycznego i środków dydaktycznych, z których korzysta na co dzień, w tym z komputera. Czas przeznaczony na przeprowadzenie egzaminu może być przedłużony nie więcej niż o 30 minut. Ponadto podczas w części praktycznej egzaminu istnieje możliwość zapewnienia obecności oligofrenopedagoga, jeśli jest to niezbędne do uzyskania właściwego kontaktu z uczniem oraz pomocy w obsłudze specjalistycznego sprzętu i środków dydaktycznych. Wszelkie dostosowania przewidziane dla uczniów z niepełnosprawnością intelektualną w stopniu lekkim dotyczą jedynie warunków przeprowadzania egzaminu, natomiast nie odnoszą się do jego formy. Uczniowie z niepełnosprawnością intelektualną w stopniu lekkim wypełniają taki sam arkusz egzaminacyjny jak ich pełnosprawni intelektualnie koledzy. Rozwiązaniu temu przyświeca założenie, iż każdy absolwent po pozytywnym złożeniu egzaminu zawodowego otrzymuje 
dyplom potwierdzający kwalifikacje zawodowe, które powinny być porównywalne, bez względu na rodzaj ukończonej szkoły. Znaczny procent absolwentów szkół specjalnych nie jest jednak w stanie sprostać stawianym wymaganiom egzaminacyjnym.

Czesław Jarosz [2006] przedstawiając rezultaty egzaminów przeprowadzonych przez łomżyńską OKE zwraca uwagę na fakt, iż wśród absolwentów szkół specjalnych przystępujących do egzaminu zawodowego w zawodzie kucharz małej gastronomii, potwierdzono kwalifikacje zawodowe u około $50 \%$ uczniów. $Z$ jednej strony wynik ten można uznać za niski, z drugiej zaś można zinterpretować go pozytywnie. Wszak mimo niższych możliwości połowa spośród przystępujących do egzaminu absolwentów podołała wymaganiom, którym nie zawsze są w stanie sprostać uczniowie pełnosprawni.

Ukończenie szkoły zawodowej dla ucznia z niepełnosprawnością intelektualną w stopniu lekkim najczęściej oznacza koniec edukacji. Zdarzają się jednak sytuacje, iż absolwent szkoły zawodowej, po zakończeniu nauki wybranego zawodu, podejmuje kształcenie w kolejnym zawodzie [zob. Sadownik 2011, s. 322]. Sytuacje tego rodzaju niekoniecznie są dowodem szczególnego zainteresowania edukacją i potrzeby poszerzania kwalifikacji. Wskazują one raczej na niemożność znalezienia zatrudnienia lub odnalezienia się na rynku pracy. Jest to więc swoista forma ukrytego bezrobocia absolwentów zasadniczych szkół zawodowych specjalnych.

\section{Aktywność zawodowa - wyjście z niepełnosprawności?}

Jak słusznie zauważa Wolfensberger [za Otrębski 2001, s. 12], dotąd nie będzie można mówić o normalizacji życia osób z niepełnosprawnością intelektualną w stopniu lekkim, dopóki nie będą one podejmowały ról społecznych postrzeganych przez środowisko jako wartościowe i nobilitujące w oczach innych. Rolą o takim charakterze jest rola pracownika potrafiącego zarobić na swe utrzymanie. Niestety zdecydowana większość absolwentów zasadniczych szkół zawodowych specjalnych zasila grono bezrobotnych, część trafia do warsztatów terapii zajęciowej5 i tylko nieznaczna grupa podejmuje aktywność na otwartym rynku pracy. Większość osób z niepełnosprawnością intelektualną, to osoby długotrwale bierne zawodowo, a ich poziom zatrudnienia i aktywności ekonomicznej jest zde-

\footnotetext{
Należy zwrócić uwagę, że nie każda osoba, która została zdiagnozowana jako upośledzona umysłowo w stopniu lekkim może być aktywizowana zawodowo w WTZ. Potencjalnym uczestnikiem WTZ może być osoba powyżej 16 roku życia, która posiada orzeczenie o stopniu niepełnosprawności wydane przez Powiatowe Ośrodki ds. Orzekania o Stopniu Niepełnosprawności, a ponadto w dokumencie tym ma wskazane uczestnictwo w terapii zajęciowej
} 
cydowanie niższy, nie tylko w porównaniu z populacją ogólną, ale również w porównaniu do osób z innymi rodzajami niepełnosprawności [Prawa osób z niepetnosprawnościq intelektualnq..., 2005, s. 21-22].

Skala bezrobocia wśród osób z niepełnosprawnością intelektualną w stopniu lekkim nie jest dokładnie znana, ponieważ osoby te w życiu dorosłym są trudne do zidentyfikowania. Orzeczenie o niepełnosprawności wydane przez poradnię psychologiczno-pedagogiczną jest dokumentem honorowanym tylko w systemie edukacji. Jeśli osoby te nie spełniają warunków pozwalających na uzyskanie prawnego statusu osoby niepełnosprawnej poświadczonego orzeczeniem wydawanym przez Zakład Ubezpieczeń Społecznych lub Powiatowe Ośrodki ds. Orzekania o Stopniu Niepełnosprawności, to w obszarach pozaszkolnych funkcjonują wedle powszechnych praw i zasad. Nie mogą liczyć na żadne ułatwienia przy ubieganiu się o zatrudnienie, nie mogą korzystać z systemu rehabilitacji zawodowej i społecznej oraz z ewentualnych programów tworzonych z myślą o osobach niepełnosprawnych, są zmuszone poszukiwać pracy na zasadach ogólnie obowiązujących [Prawa osób z niepetnosprawnościq intelektualną..., 2005, s. 87]. Można rzec, że wedle przepisów prawa po ukończeniu edukacji przestają być niepełnosprawne.

Trudność w zidentyfikowaniu dorosłych osób z niepełnosprawnością intelektualną w stopniu lekkim wydaje się być głównym powodem braku badań, ukazujących ich funkcjonowanie w rolach wyznaczonych przez dorosłość. Sposobem pozwalającym uzyskać wiedzę w tym zakresie jest śledzenie losów absolwentów, którzy w okresie edukacji mieli orzeczenie o niepełnosprawności intelektualnej $\mathrm{w}$ stopniu lekkim. Badania $\mathrm{z}$ tego zakresu często były podejmowane w poprzednim stuleciu [Felhorska, Urbańska 1964; Urbańska 1974; Berling 1975; Łaś 1975; Pańczyk 1976, 1987; Chodyła 1978; Górecki 1978; Śliwka 1978]. Oczywistym jest jednak, że z racji wielu zmian, które od tamtego czasu wystąpiły w życiu społecznym i gospodarczym, a także w systemie edukacyjnym, wyniki wspomnianych badań straciły na aktualności. Należy stwierdzić, że dorosłość osób z niepełnosprawnością intelektualną $\mathrm{w}$ stopniu lekkim jest obecnie kwestią przemilczaną i nierozpoznaną przez badaczy.

\section{Rekomendacje dla praktyki pedagogicznej}

Namysł nad sytuacjami, z którymi w biegu swego życia mierzą się uczniowie $\mathrm{z}$ niepełnosprawnością intelektualną w stopniu lekkim, skłania do poszukiwania rozwiązań umożliwiających wyrwanie się z trybów trajektoryjnych lub przynajmniej pozwalających minimalizować ich niekorzystne skutki, bądź przejąć nad 
nimi kontrolę. Konieczne działania powinny być podejmowane przy uwzględnieniu trójpodmiotowego modelu pedagogicznych relacji: rodzice - dziecko szkoła [zob. Kawula 1999, s. 71]. Aby rozwiązania projektowane wobec każdego z wymienionych podmiotów odznaczały się trafnością, należy na podstawie znajomości sytuacji nazwać występujące problemy i trudności, a następnie ustalić realne możliwości ich wdrożenia.

Problemami jakich mogą doświadczać rodzice dzieci z niepełnosprawnością intelektualną w stopniu lekkim jest brak rozeznania w realiach systemu edukacyjnego, nie rozumienie wymagań szkoły czy też poczucie odstępstwa od oczekiwanych standardów. Zarówno wielość rozwiązań obowiązujących w systemie oświatowym, jak i zmienność regulacji prawnych sprawiają, że nawet pedagodzy nie zawsze wykazują konieczną orientację $w$ obowiązujących przepisach. Tym bardziej rodzic, znający realia systemu oświatowego jedynie z perspektywy usługobiorcy, ma problem $\mathrm{z}$ właściwym poruszaniem się w meandrach prawnych. A przecież to $\mathrm{w}$ jego gestii leży decyzyjność pozwalająca zainicjować określone działania (wnioskowanie o badanie w poradni psychologiczno-pedagogicznej, ujawnienie i uruchomienie zapisów orzeczenia, wybór ścieżki edukacyjnej, wnioskowanie o objęcie dziecka pomocą psychologiczno-pedagogiczną na terenie szkoły). Jestem przekonana, że jednym z powodów braku działania ze strony rodziców lub nieracjonalności podejmowanych przezeń decyzji jest niedoinformowanie i brak świadomości co do realiów tyczących kształcenia specjalnego. Pozostawienie rodzica $\mathrm{z}$ prawem czy też koniecznością podjęcia decyzji bez wyposażenia go $\mathrm{w}$ odpowiednią wiedzę jest poważnym zaniedbaniem skutkującym biernością lub przyjmowaniem błędnych, nietrafnych rozstrzygnięć. Wsparcie informacyjne to jedna z form pomocy, którą rodzic powinien uzyskać od nauczycieli z nim współpracujących. Ważne jest jednak, by przekaz kierowany do rodzica uwzględniał jego możliwości, a dzięki temu był zrozumiały i przydatny. Nie uwzględnianie faktu, że pomiędzy kulturą szkoły i rodziny niejednokrotnie występują znaczne różnice, może przyczyniać się do zakłóceń we współpracy rodziców i nauczycieli. Tak jak obowiązkiem pedagoga jest dostosowanie procesu edukacji do potrzeb i możliwości ucznia, tak również działania kierowane wobec rodziców powinny uwzględniać ich poziom funkcjonowania społeczno-kulturowego. Nierówne angażowanie się rodziców w życie szkoły może wynikać z faktu, że niektórzy są bagatelizowani, postrzegani jako osoby nie ubogacające przestrzeni edukacyjnej, wzywani jedynie do kontaktu w sytuacji, gdy pojawia się problem. Przerysowana asymetria ról naturalnych i profesjonalnych opiekunów dzieci daje znać o sobie wówczas, gdy nauczyciele przydzielają rodzicom podrzędne pozycje, ograniczające się do wyrażania zgody, nie traktują ich jak pełnoprawnych partnerów [Smith 2009 s. 266]. 
Zastanawiając się nad rolą rodziców w kształtowaniu drogi życiowej dzieci z niepełnosprawnością intelektualną w stopniu lekkim nie można zapomnieć, że częstym powodem prowadzącym do orzeczenia o tej niepełnosprawności są niekorzystne, niestymulujące, hamujące rozwój, społeczno-kulturowe uwarunkowania domu rodzinnego. W środowisku, które dopuszcza się takich zaniedbań, możemy się spotkać zarówno z celowym działaniem, świadomymi zachowaniami krzywdzącymi, jak i nieporadnością, nieumiejętnością podejmowania racjonalnych kroków. Poza rodzicami, którzy nie widzą potrzeby i nie chcą wprowadzać zmian w swoim postępowaniu, są również tacy, którzy są otwarci na poprawę funkcjonowania, lecz nie wiedzą co i jak należy zmienić.

Analizując uwarunkowania porażek, na jakie uczeń z niepełnosprawnością intelektualną napotyka w biegu swojego życia, skoncentruję się na wybranych właściwościach funkcjonowania tychże uczniów.

Uwidaczniająca się szczególnie w sytuacjach problemowych pasywność tylko po części może być warunkowana niskim potencjałem intelektualnym. Zaburzenia procesów orientacyjno-poznawczych, które łączą się z niepełnosprawnością intelektualną, nie sprzyjają wprawdzie pokonywaniu teoretycznych i praktycznych trudności, ale również nie blokują całkowicie możliwości rozwiązywania problemów. Niezwykle istotną przyczyną bierności są doświadczenia i umiejętności zyskiwane przez ucznia w ciągu życia. Zwalnianie z konieczności rozwiązywania problemów, wyręczanie w działaniach, bądź też stawianie zbyt złożonych, skomplikowanych zadań do wykonania, niepozwalających doświadczyć sukcesów, które mobilizowałby do dalszego wysiłku, może prowadzić do wycofania się z aktywności lub przyjmowania nieadekwatnych, przypadkowych rozwiązań. Doświadczenia w rozwiązywaniu problemów pod okiem nauczyciela mogą być podstawą i przesłanką do tego, by w sytuacjach pozaszkolnych nie omijać trudności, lecz przyjąć taką strategię, która pozwoli z sukcesem zmierzyć się z napotkanym problemem.

Innym powodem biernej, zachowawczej postawy uczniów niepełnosprawnych intelektualnie w stopniu lekkim może być przekonania o nieskuteczności własnych działań, a zatem niezasadności ich podejmowania. Mnogość niepowodzeń, na jakie w ciągu życia napotyka uczeń z niepełnosprawnością intelektualną w stopniu lekkim, budzi poczucie niewiary w swoje możliwości, nasuwa przeświadczenie, że porażka jest czymś nieuchronnym, w trwały sposób wpisanym się w doświadczenia życiowe. Poczucie bezsilności, zagrożenia, lęku, chęć uniknięcia kolejnych niepowodzeń prowokują do bierności i przyjmowania strategii unikowych, nie zachęcają do wyznaczania celów oraz podejmowania trudu ich realizacji.

Czynnikiem, który pozwala budować wiarę w swój potencjał i w swoją moc sprawczą, jest wzmacniające nastawienie otoczenia, informacja płynąca o sobie 
od innych. Informacja ta może przyjmować postać bezpośredniego komunikatu, typu: potrafisz, dasz radę, możesz to zrobić, lub niezwerbalizowana ukrywać się w zaproszeniu do określonego działania, w powierzonym zadaniu, w oferowanej funkcji. Ta druga sytuacja wiąże się ze świadomością, że złożona propozycja jest nobilitacją, a równocześnie wyrazem przekonania, iż osoba w ten sposób obdarowana jest w stanie podołać zadaniu.

Osobami znaczącymi w biegu życia każdego człowieka są pedagodzy. W założeniu ich działania powinny sprzyjać dobrostanowi uczniów, optymalizować ich rozwój, zapobiegać pojawiającym się nieprawidłowościom. Pedagodzy szczególnie istotną rolę mają do spełnienia wobec tych osób, które nie zyskują wsparcia $\mathrm{w}$ środowisku rodzinnym, a wręcz doświadczają z jego strony zaniedbań, niezrozumienia czy też przemocy. W takiej sytuacji znajduje się znaczny procent uczniów z niepełnosprawnością intelektualną w stopniu lekkim. Wbrew przedstawionym założeniom zdarza się, iż pedagodzy przejmują role „profesjonalnych operatorów trajektorii" [zob. Zakrzewska-Manterys 1995, s. 56], narzucając uczniom własne wizje rozwoju, nieuwzględniające ich podmiotowości, prawa do samostanowienia, działając wbrew ich potrzebom i realnym możliwościom. Powodami takiego postępowania mogą być zarówno właściwości osobowościowe pedagogów, jak też odmienności doświadczeń życiowych nauczycieli i uczniów, utrudniające wzajemne zrozumienie. Odrębność doświadczeń nie musi całkowicie blokować możliwości wzajemnego zrozumienia i skutecznej współpracy, pod warunkiem, iż pedagog nie będzie ograniczał się do roli dydaktyka, lecz wykaże autentyczne zainteresowanie sytuacją pozaszkolną uczniów, ujawni wrażliwość i otwartość na ich potrzeby. Jedna osoba dorosła, osobiście przejęta losem ucznia, wykazująca zaangażowanie i zrozumienie dla jego sytuacji może skutecznie zapobiegać egzystencji na marginesie życia społecznego, tworzyć przestrzeń do rozwoju [zob. Sadownik 2011, s. 321].

Na podstawie przeprowadzonych rozważań można sformułować rekomendacje, których zastosowanie pozwoliłoby bardziej świadomie osobom z niepełnosprawnością intelektualną w stopniu lekkim kształtować trajektorię swojego życia.

- Podejmowanie działań $w$ ramach wczesnej interwencji w postaci pomocy udzielanej rodzicom oraz wczesnej intensywnej stymulacja psychospołecznego rozwoju dziecka jako przeciwdziałanie powstawaniu kulturowej niepełnosprawności intelektualnej [zob. Głodkowska 1999, s. 7].

- Budowanie relacji współpracy pomiędzy szkołą i domem ucznia, tworzenie sieci wsparcia, angażowanie rodzin w życie szkoły, ze szczególnym uwzględnieniem środowisk o niskim kapitale kulturowym i ekonomicznym.

- Traktowanie rodziców jako pełnoprawnych partnerów, decydujących w dużym stopniu o losach dziecka. 
- Dostosowanie działań i przekazu kierowanego wobec rodziców do ekonomicznego i kulturowego poziomu rodziny.

- Przezwyciężanie niewiary we własną skuteczność u osób z niepełnosprawnością intelektualną $\mathrm{w}$ stopniu lekkim poprzez ujawnianie nieuświadamianych wcześniej możliwości, pozwalających podejmować aktywności dotychczas nieznane, osiągać budzące zaskoczenie rezultaty.

- Rozwijanie aktywności, wzmacnianie autonomii, kształtowanie samosterowności, zachęcanie do przejęcia kontroli nad własnym losem, zmuszanie do walki o samego siebie, prowokowanie do wprowadzania twórczych zmian.

- Wyznaczanie realnych celów, pozwalających budować orientację ku przyszłości.

- Tworzenie spirali życzliwości [zob. Kawula 1999, s. 50], bazującej na akceptacji osoby z niepełnosprawnością intelektualną w stopniu lekkim, wrażliwości na jej potrzeby, umożliwiającej udzielanie wsparcia adekwatnego do sytuacji. Wsparcie to powinno prowadzić do samorozwoju osoby niepełnosprawnej, wzrostu jej zaradności życiowej, a w rezultacie umożliwić życie na własny rachunek.

\section{Bibliografia}

Berling Z. (1975), Przygotowanie młodzieży upośledzonej umysłowo do życia społecznego, „,Szkoła Specjalna", nr 1.

Bobeł B. (2003), Postawy rodziców wobec możliwości integracji szkolnej dzieci o specjalnych potrzebach edukacyjnych [w:] Integracja osób niepetnosprawnych w edukacji i interakcjach społecznych, Z. Kazanowski, D. Osik-Chudowolska (red.), Wydawnictwo UMCS, Lublin.

Borzyszkowska H. (1997), Izolacja społeczna rodzin majacych dziecko upośledzone umysłowo w stopniu lekkim, Wydawnictwo Uniwersytetu Gdańskiego, Gdańsk.

Brzezińska A.I., Ohme M., Resler-Maj A., Kaczan R., Wiliński M. (2009), Jak wspomagać rozwój dzieci i młodzieży z ograniczeniami sprawności, GWP, Gdańsk.

Chodyła B. (1978), Adaptacja zawodowa upośledzonych umysłowo zatrudnionych w spótdzielczości inwalidzkiej [w:] O integracje społeczna młodocianych i dorostych upośledzonych umystowo, I. Wald (red.), WSiP, Warszawa.

Felhorska F., Urbańska B., Wojtaszek Z. (1964), Losy absolwentów szkót specjalnych dla dzieci upośledzonych umystowo, PZWS, Warszawa.

Gajdzica Z. (2007), Edukacyjne konteksty bezradności społecznej osób z lekkim upośledzeniem umysłowym, Wydawnictwo Uniwersytetu Śląskiego, Katowice.

Gebreselassie J. (2011), Rodzina ucznia szkoły specjalnej partnerem w procesie edukacji-oczekiwania i rzeczywistość, „Niepełnosprawność", nr 6.

Giermanowska E. (2007), Zatrudnienie młodych osób niepetnosprawnych w opiniach pracowników Powiatowych Urzędów Pracy [w:] Młodzi niepełnosprawni-aktywizacja zawodowa i nietypowe formy zatrudnienia, E. Giermanowska (red.), Wydawnictwo ISP, Warszawa.

Głodkowska J. (1999), Poznanie ucznia szkoły specjalnej, WSiP, Warszawa. 
Gołubiew-Konieczna M. (2012), Dzieci i młodzież niepetnosprawna w perspektywie uptywającego czasu i w procesie szkolnej edukacji [w:] Dyskursy Pedagogiki Specjalnej 10. Szkoła dla osób z niepetnosprawnością. Wzory - Codzienność- Wyzwania?, A. Krause, I. Belzyt, S. Sadowska (red.), Wydawnictwo Uniwersytetu Gdańskiego, Gdańsk.

Gołubiew M., Krause A. (2007), Szkolnictwo specjalne - krajobraz po reformie [w:] Problemy edukacji integracyjnej dzieci i młodzieży z niepetnosprawnościa intelektualna, Z. Janiszewska-Nieścioruk (red.), Oficyna Wydawnicza „Impuls”, Kraków.

Górecki B. (1978), Znaczenie społeczne przygotowania zawodowego upośledzonych umysłowo [w:] O integrację społeczna młodocianych $i$ dorostych upośledzonych umystowo, I. Wald (red.), WSiP, Warszawa.

Grzyb B. (2013), Uwarunkowania zwiąane z przenoszeniem uczniów niepetnosprawnych ze szkót integracyjnych do specjalnych, Oficyna Wydawnicza "Impuls”, Kraków.

Gustavsson A. (1997), Integracja, stygmatyzacja, autonomia - jasne i ciemne strony subkultury integracji [w:] Upośledzenie w społecznym zwierciadle, red. A. Gustavsson, E. Zakrzewska-Manterys, Wydawnictwo „Żak”, Warszawa.

Hołub J. (2017), Trudna droga od nauki do pracy, "Integracja”, nr 1

Janiszewska-Nieścioruk Z. (1999), Samoocena dzieci lekko niepetnosprawnych intelektualnie a stan ich społecznej integracji w środowisku rodzinnym [w:] Człowiek niepełnosprawny. Zagrożenia $i$ szanse rozwoju, B. Aouil (red.), Wydawnictwo Uczelniane WSP, Bydgoszcz.

Jarosz Cz. (2006), Egzaminowanie zewnętrzne - potwierdzenie kwalifikacji zawodowych uczniów z lekkq niepetnosprawnością intelektualnq [w:] Rehabilitacja spoteczna i zawodowa osób z niepetnosprawnościa intelektualnq - od bierności do aktywności, J. Głodkowska, A. Giryński (red.), Wydawnictwo Naukowe „Akapit”, Warszawa.

Kawula (1999), Człowiek w relacjach socjopedagogicznych, Wydawnictwo Edukacyjne „Akapit", Toruń,

Kościelak R. (1989), Psychologiczne podstawy rewalidacji upośledzonych umysłowo, PWN, Warszawa.

Kościelska M (1984), Upośledzenie umysłowe a rozwój społeczny, PWN, Warszawa.

Kościelska M. (1995), Oblicza upośledzenia, PWN, Warszawa.

Kozubska A. (2000), Opieka i wychowanie w rodzinie dziecka upośledzonego umysłowo w stopniu lekkim, Wydawnictwo Uczelniane Akademii Bydgoskiej, Bydgoszcz.

Krause A. (2004), Człowiek niepetnosprawny wobec przeobrażeń społecznych, Oficyna Wydawnicza „Impuls”, Kraków.

Krause A. (2010), Wspótczesne paradygmaty pedagogiki specjalnej, Oficyna Wydawnicza „Impuls”, Kraków.

Krause A., Wielowymiarowość edukacji osób niepetnosprawnych a kształcenie integracyjne - dylemat szczęścia [w:] Wielowymiarowość edukacji osób z niepetnosprawnościa, Cz. Kosakowski, ks. C. Rogowski (red.), UWM, Olsztyn 2005.

Kwieciński Z. (2002), Wykluczenie, Wydawnictwo Uniwersytetu Mikołaja Kopernika, Torun.

Łaś H. (1975), Proces spotecznej rewalidacji uczniów szkót specjalnych dla upośledzonych umysłowo, IKNiBO, Poznań.

Materny K. (2005), „Moje miejsce w świecie” - doświadczenia edukacyjne i społeczne młodzieży $z$ niepetnosprawnością intelektualna [w:] Normalizacja środowisk życia osób niepetnosprawnych. Dyskursy pedagogiki specjalnej 4, Cz. Kosakowski, A. Krause (red.), UWM, Olsztyn. 
Mikiewicz P. (2005), Społeczne światy szkót średnich: od trajektorii marginesu do trajektorii elit, Wydawnictwo Naukowe Dolnośląskiej Szkoły Wyższej Edukacji TWP, Wrocław.

Minczakiewicz E.M. (2003), Młodzież niepetnosprawna i jej rodzice wobec integracji edukacyjnej [w:] Integracja osób niepetnosprawnych w edukacji i interakcjach społecznych, Z. Kazanowski, D. Osik-Chudowolska (red.), Wydawnictwo UMCS, Lublin.

Moulin J.P. (1996), Problemy integracji dzieci niepetnosprawnych [w:] Problemy edukacji i rewalidacji dzieci niepetnosprawnych, J. Pilecki, M.A. Winzer (red.), Wydawnictwo Naukowe WSP, Kraków.

Obuchowska I. (1997), Diagnoza psychologiczna w poradniach psychologiczno-pedagogicznych, „Problemy Poradnictwa Psychologiczno Pedagogicznego. Biuletyn”, nr 2 (7).

Olszewski S. (1995), Poziom samooceny i samoakceptacji uczniów upośledzonych umysłowo w stopniu lekkim a ich pozycja socjometryczna w zespole klasowym, Rocznik Naukowo-Dydaktyczny WSP w Krakowie, z. 175, Prace Pedagogiczne XVIII.

Olszewski S., Parys K. (2004), W poszukiwaniu optymalnych rozwiązań dotyczacych edukacji osób niepetnosprawnych [w:] Rehabilitacja, opieka i edukacja specjalna w perspektywie zmiany, Cz. Kosakowski, A. Krause (red.), Wydawnictwo UWM, Olsztyn

Ostrowska A., Mirkowska-Mankiewicz A. (1978), Społeczne uwarunkowania lekkiego upośledzenia umystowego [w:] O integracje społeczna młodocianych $i$ dorostych upośledzonych umystowo, WSiP, Warszawa.

Otrębski W. (2001), Osoby z upośledzeniem umysłowym w sytuacji pracy, Towarzystwo Naukowe KUL, Lublin.

Otrębski W. (2007), Interakcyjny model rehabilitacji zawodowej osób z upośledzeniem umysłowym, Wydawnictwo KUL, Lublin.

Pańczyk J. (1976), Przygotowanie społeczno-zawodowe chłopców upośledzonych umysłowo w stopniu lekkim na przykładzie zawodu ślusarza [w:] Wybrane zagadnienia z oligofrenopedagogiki, K. Kirejczyk (red.), WSPS, Warszawa

Pańczyk J. (1987), Kształcenie zawodowe młodzieży upośledzonej umysłowo w stopniu lekkim, PWN, Warszawa

Pańczyk J. (1996), Pedagogika specjalna w Polsce u progu XXI wieku [w:] Demokracja a oświata, ksztatcenie i wychowanie. Materiały z II Ogólnopolskiego Zjazdu Pedagogicznego, H. Kwiatkowska, Z. Kwieciński (red.), Polskie Towarzystwo Pedagogiczne, Toruń.

Parys K., Olszewski S. (2003), Dla kogo integracja? [w:] Dyskursy pedagogiki specjalnej - konteksty teoretyczne, Cz. Kosakowski, A. Krause (red.), Wydawnictwo UWM, Olsztyn.

Pilecka W. (2000), Psychoruchowy rozwój dzieci o obniżonej sprawności umysłowej [w:] Stymulacja psychoruchowego rozwoju dzieci o obniżonej sprawności umysłowej, W. i J. Pileccy (red.), Wydawnictwo Naukowe UP, Kraków.

Prawa osób z niepetnosprawnościa intelektualną. Dostęp do edukacji i zatrudnieni. Raport (2005), Polskie Stowarzyszenie na Rzecz Osób z Upośledzeniem Umysłowym, Warszawa.

Rokuszewska-Pawełek A, ( 2002 ). Chaos i przymus. Trajektorie wojenne Polaków - analiza biograficzna, Wydawnictwo Uniwersytetu Łódzkiego, Łódź.

Rozporządzenie MEN. z dnia 27 kwietnia 2015 r. w sprawie szczegółowych warunków i sposobu przeprowadzania egzaminu potwierdzającego kwalifikacje $\mathrm{w}$ zawodzie, Dz. U. z 2015 r., poz. 673. 
Rozporządzenie MEN z dnia 13 grudnia 2016 roku w sprawie klasyfikacji zawodów szkolnictwa zawodowego, Dz. U. z 2016 r., poz. 2094.

Rozporządzenie MEN z dnia 13 marca 2017 r. w sprawie klasyfikacji zawodów szkolnictwa zawodowego, Dz. U. z 2017 r., poz. 622.

Rozporządzenie MENiS z dnia 8 maja 2004 r. w sprawie klasyfikacji zawodów szkolnictwa zawodowego, Dz. U. z 2004 r. Nr 114, poz. 1195.

Różycka J. (1959), Dziecko o obniżonej sprawności umysłowej, Zakład Narodowy im. Ossolińskich, Wrocław.

Sadownik A. (2011), Na rozstajnych drogach. Studium etnopedagogiczne kontrastowych karier szkolnych młodzieży, Wydawnictwo Naukowe Dolnośląskiej Szkoły Wyższej, Wrocław.

Sadowska S. (2005), Ku edukacji zorientowanej na zmianę społecznego obrazu osób niepetnosprawnych, Wydawnictwo Edukacyjne Akapit, Torun.

Sadowska S. (2006a), Jakość życia uczniów z niepetnosprawnościq intelektualna w stopniu lekkim, Oficyna Wydawnicza „Impuls”, Kraków.

Sadowska S. (2006b), Ścieżka edukacyjna uczniów z niepetnosprawnościa intelektualna w stopniu lekkim - aspekty trajektorii społecznej, „Szkoła Specjalna”, $\mathrm{nr} 5$.

Smith D.D. (2009), Pedagogika specjalna 2. Podręcznik akademicki, Wydawnictwo APS, Wydawnictwo Naukowe PWN, Warszawa.

Śliwka M. (1978), Losy absolwentów zasadniczej szkoły zawodowej specjalnej [w:] O integracje społeczna młodocianych i dorostych upośledzonych umystowo, I. Wald (red.), WSiP, Warszawa

Urbańska B. (1974), Losy absolwentów zasadniczych szkół zawodowych specjalnych, WSiP, Warszawa

Ustawa z dnia 7 września 1991 r. o systemie oświaty, Dz. U. z 1991 r. Nr 95, poz. 425.

Wojciechowski F. (1990). Dziecko umystowo upośledzone w rodzinie. WSiP, Warszwa.

www.cke.edu.pl/images/_KOMUNIKATY/Komunikat\%20o\%20dostosowaniach\%2020162017.pdf [dostęp: 17.05.2017].

Zakrzewska-Manterys E. (1995), Down i zespót wątpliwości. Studium z socjologii cierpienia, Semper, Warszawa. 